\title{
OPERATING CASH FLOW AND EARNINGS MANAGEMENT: EVIDENCE FROM NIGERIAN BANKS
}

\author{
Osisioma, Benjamin C. ${ }^{1}$, Okoye, Pius V. C. ${ }^{2}$, Ezejiofor, Raymond A. ${ }^{3}$ and \\ Okoye, Janefrances $\mathrm{N}^{4}{ }^{4}$ \\ Department of Accountancy \\ Nnamdi Azikiwe University, Awka \\ Mail: benosisioma@yahoo.com ${ }^{1}$; vynopee@gmail.com ${ }^{2}$, thaddray4life@yahoo.com $^{3}$ \\ and janeokoye72@gmail.com ${ }^{4}$
}

\begin{abstract}
This study assesses the effect of operating cash flow on earnings management of Nigerian Banks. The study adopted Ex post Facto research design. The study used sample of fifteen (15) Nigerian banks from 2010 to 2019. Data for the study was collected from annual reports and accounts of the banks. Regression analysis was used to test the hypothesis with the aid of E-view 9.0. Based on this, the study revealed that operating activities are not statistically significant and have a negative effect on total accruals earnings of Nigerian banks. The study concludes that the importance of risk management activities is aimed at reducing future cash flow. Based on this, the researcher recommended among others that managers should be more likely to opportunistically boost operating cash flows if the firm has a cash flow forecast like engaging in principal financing source for maintaining the operating capability of the entity in terms of repaying loan and making new investment.
\end{abstract}

Keywords: Operating activities, cash flow, and earnings management 


\section{INTRODUCTION}

It is notable that according to the agency theory, both managers and shareholders groups (owners) try to increase their profit (Nia, Vaeez, \&. Ahmadi, 2013), but the profit is always subject to management's control. The company has all beneficiary parties considering the cash flows because they see their profits in the form of output cash flows (Fatma \& Chichti, 2011).

The reported operating cash flow indicates the company's capability to make the cash flow. The financial analysts believe that the cash flow from the operating activities with the investment opportunities should be spent on the distribution of the profits among the shareholders and increase their satisfaction (Bandia, 2012).

Mcinnis and Collins (2011) documented that cash flow forecasts constrains a firm's opportunity to manage earnings as investors can project the forecasted accruals with the information from both earnings and cash flows, and monitor a firm's financial reporting accordingly. However, cash flows forecast itself are also an important benchmark for firms. Investors reward firms that meet both targets (Brown \& Pinello, 2011), hence firms have strong incentives to meet cash flows forecast in addition to earnings forecast. To do so, they may alter their earnings management activities, especially real earnings management as it directly affects the firm's cash flows.

Earnings management transpire when managers use verdict in financial reporting to adjust financial reports to either mislead some stakeholders about the underlying economic performance of the company or to control the contractual outcomes that depend on reported accounting figures. The first advantage was the approach allows researchers to advance instinct for the important features that impact the behavior of the accrual, while the second advantage was that the approach could be useful in industries, where a certain form of trade can result in a specific accrual being material. However, he noted problems attributed to measuring earnings management through definite accruals do not affect banks and insurance because some particular accruals accounts are very essential (Musa \& Muhammad, 2018). This was as a result of the specific nature of the business, and since it is composed of large accruals for banks and its provision also has a noticeable influence on earnings, a loan loss provision is an important tool for earnings management in the banking sector.

Many studies have also been carried out on cash flow and earnings management, the results from the empirical evidence on the effects of cash flow on earnings management are inconsistent and some are contradictory; ranging from positive, to negative. However, the lack of consensus on the empirical literature calls for further studies on the study of this nature. Besides, most of these prior studies were carried out in foreign countries on manufacturing companies. The inconsistency on the part of previous studies professes strong justification for this work. It is in this light, this study seeks up to determine the effect of cash flow operating activities on earnings management of quoted Nigerian Banks. It is worthy of being examined especially in the listed DMBs in Nigeria. 
Journal DOI: 10.46654/ij.24889849

\section{REVIEW OF RELATED LITERATURE}

\section{Earnings Management}

Earnings management is represented by the discretionary accruals of the firm which is distilled from the total accruals. Prior studies identify three methods firms generally employed to achieve earnings targets: accrual management, expectation management, and real earnings management. Among these three avenues, survey results by Graham, Harvey, and Rajgopal, (2005) show that managers prefer real activities management to accruals management as a way to manage earnings. Further, in the post-SOX period, there is a shift from accrual management to real earnings management (Cohen, Dey \& Lys 2008). That shift is coincident with the spike of cash flow forecast (Call, 2009). Firms, therefore, turn to real earnings management and earnings guidance (McInnis \& Collins, 2011).

Different from accrual manipulation, firms engage in real activities management during the fiscal year because if the realized year-end earnings fall out of the threshold, it is too late to manipulate real activities at year-end. Roychowdhury (2006) defines suspect firm-years as those with small positive earnings and he finds suspect firm-years have higher abnormal production costs, lower abnormal discretionary expenses, and lower abnormal cash flows. Before this time, the Authors recognized the fact that firms manage income for purposes of tax, the confidence of the shareholders, and expectations which are likely to follow the report of high earnings. But attention on the use of discretion to manage earnings, received worldwide drive after the crisis of Enron and other cases which was similar to cases of earnings management that came up. Most literature has acknowledged that loan losses also play significant roles in the financial crises witnessed, whose provision had a direct effect on companies' cash flows and also the earnings reported by them (Chang, Shen, \& Fang, 2008; Mohammad, Wasiuzzaman, \& Zaini, 2011).

Loan loss provision is an expense that shows the managers' evaluation of projected future losses. This signifies an increase in loan loss provision reduces net income and vice versa. Since loan loss provision shows how managers' project likely loss that a firm would incur if their debtors refuse to settle their debt when due, then the provision for it, is considered to have two parts: the discretionary and the non-discretionary portions. The Non-discretionary is a function of specific quality determinants in the loan portfolio over 90 days, and specific analyses on troubled large credits, which implies an internal grading system (Gray, \& Clarke, (2004). The discretionary portion is those accruals that largely depend on the outcome of the managers' future expectation of uncertain events while the non-discretionary portion, therefore, is the provision that is based on fair and objective analysis of the firm's economic conditions (Mohammad et al, 2011).

\section{Cash flows}

Studies on analysts' cash flow have increased recently. Defond and Hung (2003) show that analysts' propensity to produce cash flows forecast increases with the magnitude of accruals, heterogeneity of accounting method, earnings volatility, capital intensity, and financial distress. Analysts are more likely to issue cash flow forecast in countries where investor protection is poor and earnings are of a lower quality (Defond \& Hung, 2007). Ertimur and Stubben (2005) 
find that analysts from bigger brokerage houses, who have less accurate prior earnings forecast, are more likely to provide cash flow forecast.

Prior studies also provide strong evidence that firms have incentives to meet analysts' forecasts. Bartov, Givoly, and Hayn (2002) find that firms meeting analysts' earnings forecast experience favorable market reactions. Defond and Hung (2003) document similar results for firms meeting cash flow as the additional cash flow alter managerial behaviors. Mcinnis and Collins (2011) found that cash flows forecast increases the quality of reported accruals and reduces the likelihood that firms will meet or surpass earnings target, consistent with the notion that cash flows forecast is driven by concerns over earnings quality. Besides, cash flows also convey information about future cash flows. Call (2009) finds that analysts' cash flows forecast checkmates managers and creates incentives for managers to report more informative cash flow data.

Operating cash flow is cash flow from the principal revenue-producing activities, which involve the cash effect of transactions that enter into the determination of net income in the income statement. Operating cash flow is used to determine whether the operation of the company is sufficient to repay short-term debt and to pay the costs related to the operation of the company. Operating cash flow shows cash receipts and expenditures of the company's operations.

Management boosts sales by giving discounts and credit term payment for goods sold. This will improve on sales, as well as profits generated by the company, but will affect the cash flow statement of operational activities. The cash flow of operational activities of the company will be lower than if the company is selling normally. The company receives this small cash because of an increase in accounts receivable due to the company selling on credit and the discounted price that requires the company to cut the price of the sale (Ji'ah and Pujiati, 2013).

\section{Empirical Review}

Lanouar, Rabeb and Abdelwahed (2018) ascertained the determinants of earnings management in emerging countries of Tunisian. They considered two types of factors of earnings management: incentives factors and constraints factors. Their empirical analysis is conduct by using data relative to 19 Tunisian listed companies collected from the Tunisian stock exchange during the period 2003 - 2009. Empirical results show that on the whole results seem to depend on the model used to estimate discretionary accruals. Tarek (2017) examined the country-level determinants of accruals-based earnings management and real activities-based earnings management of firms in the MENA region. A pooled cross-sectional regression is used to test a sample of 802 nonfinancial firms listed on the stock exchanges of Bahrain, Egypt, Jordan, Kuwait, Morocco, Oman, Qatar, Saudi Arabia. The study found that Altman's Z-Score, and earnings management have a positive effect on discretionary accruals while firm size, growth opportunities, the dividend payout ratio, and asset tangibility are negative effect on discretionary accruals. Yulius, Arya and Indra (2017) examined the effect of board of commissioner, the board independence and audit quality on the relationship between free cash flow and earnings management. The study revealed that board of commissioner, board independence, and audit quality has significant but negative effect free cash flow and earnings management. Hossein and Gaskari (2016) evaluated the effect of cash flow volatility and financial leverage on earnings management in companies listed on the Tehran Stock Exchange (TSE). Using Chow and Hausman tests. The results of models estimation 
suggest the confirmation of research hypotheses. Therefore, "cash flow fluctuations" in studied companies has a significant positive effect and "leverage ratio" has a significant negative effect on earnings management. Mehdi, Ines, Tawhid and Faten (2016) analyzed the moderating effect of corporate governance and ownership features in lessening earnings management practices in a free cash flow (FCF) situation. A simultaneous equations model is developed to address the endogeneity of the FCF variable. The results highlight the opportunistic behavior of managers in presence of free cash flows. Their results also show that corporate governance mechanisms such as audit committee independence and external audit quality, in addition to institutional investors and managerial ownership reduce the extent of earnings management. Slavko (2015) ascertain how fair values are used in financial reports is related to the earnings quality in Eastern European countries. The result shows that both firms and banks with increased exposure to fair value accounting in financial reporting have lower level of aggregate earnings quality. Aries (2015) determined the effect of leverage and firm size on earnings management. Using SPSS for Windows version 20, showed that the value of operating leverage coefficient of 0.215 , significant operating leverage affect earnings management. Aja and Brossa (2014) using a survey on the relationship between cash flow volatility, financial leverage and earnings management of 9776 companies in USA. The study found that cash flow has a significant positive relationship with earnings management while leverage ratio has a negative significant with earnings management. Nacasius and Jorge (2014) ascertained the effect of cash flow volatility and leverage on earnings management across industries. The study found that financial leverage and cash flow have effect earnings. Rahmani and Akbari, (2013) evaluated the affecting level of firm size and capital structure on earnings management. Data were collected from 75 listed firms for the period from 2006 to 2010. The asset is a proxy of firm size, financial leverage is a proxy of capital structure and accrual is a surrogate of earnings management. The results concluded that capital structure has a negative relationship with earnings management. Norhayati, Rahayu and Noor (2013) evaluated the association between leverage and Real Earnings Management (REM) activities. The study found significant negative association between leverage and REM. The finding reveals that leveraged firms have lower levels of REM. This supports the view that leverage limits the REM activities, which in turn, could affect the quality of accounting earnings. Alves (2012) examined the relationship between the corporate ownership structure in Portugal and earnings management. Using a sample of 34 non-financial listed Portuguese firms for years from 2002 to 2007, they find that discretionary accruals as a proxy for earnings management is negatively related both to managerial ownership and to ownership concentration. It was revealed that managerial ownership and ownership concentration improve the quality of annual earnings as it reducing earnings management level. Bandia (2012), through a research on listed companies on India Stock Exchange, has carried out a survey on the relationship between free cash flow and earnings management. The results of the research showed that a significant positive relationship exists between earnings management and free cash flow.

The results from the empirical evidence on the effects of cash flow on earnings management are inconsistent and some are contradictory; ranging from positive, to negative. However, the lack of consensus on the empirical literature calls for further studies on the study of this nature. Besides, most of these prior studies were carried out in foreign countries. The inconsistency on the part of previous studies professes strong justification for this work. 
Journal DOI: 10.46654/ij.24889849

\section{METHODOLOGY}

Ex post facto research design which is the aspect of statistic that involves the various techniques of describing data collections has been adopted for this research. This design enabled the researcher to describe and summarize the data collected for the study.

The population of this study is sixteen Listed Deposit Money Banks quoted on the Nigerian Stock Exchange as at 2019. These banks are as follows; Access bank plc; Diamond bank plc; First bank plc; Skye bank plc; FCMB plc; GTB plc; Zenith bank plc; Sterling bank plc; UBA plc; Fidelity bank plc; Stanbic IBTC; Union bank plc; Unity Bank Plc; Wema bank plc; Eco bank Plc and Chartered standard bank plc.

\section{Method of Data Analysis}

Simple Regression Analysis was used to analyze the data collected for the study. This was done with aid of the E-view 9.0. The hypothesis was tested at 95\% confidence level.

\section{Model Specification}

The model is stated below:

$\mathrm{Y}=\beta_{\mathrm{o}}+\beta_{1} \mathrm{X}_{1}+\mu$

Where:

$\mathrm{Y}=$ Earning Management (dependent variable)

$\mathrm{X}=$ Cash flow from operating activities (independent Variable)

$\beta_{0}=$ constant term (intercept)

$\beta_{1}=$ Coefficients of financial leverage

$\mu \quad=\quad$ Error term (stochastic term)

Explicitly, the equation can be defined as:

Earning Management $=\quad f($ Cash flow from operating activities $)+\mu$

Representing the equations with the variables of the construct, hence the equations below are formulated:

ENMGT $_{\text {it }}=\beta_{0}+\beta_{1}$ CFOPA $_{\text {it }}+\mu_{\text {it }}-\quad-\quad-i$

\section{Where:}

$\beta_{0}=$ Constant term (intercept)

$\beta_{\text {it }}=$ Coefficients to be estimated for bank $i$ in period $\mathrm{t}$

$\mu_{\text {it }}=$ Error term/Stochastic term for bank $i$ in period $\mathrm{t}$

ENMGT $_{\text {it }}=$ Earnings per Share of bank $i$ in period $t$

$\mathrm{CFOPA}_{\text {it }}=$ Cash flow from operating activities of bank $i$ in period $\mathrm{t}$ 
Journal DOI: 10.46654/ij.24889849

Article DOI: 10.46654/ij.24889849.s61221

\subsection{Decision Rule}

Reject $\mathrm{H}_{\mathrm{o}}$ if the P-value of the test is less than $\alpha$-value (level of significance) at $5 \%$, otherwise accept $\mathrm{H}_{\mathrm{I}}$

\section{Measuring Dependent Variable (Earnings Management)}

This study used the modified Jones's model (Dechow et al., 1995) to measure the level of earnings management or discretionary accruals (DTAC). This model used total accruals (TAC) that are classified as discretionary components (DTAC) and non-discretionary components (NDTAC). Thus, defined as follows:

$\mathrm{TAC}=\mathrm{NDTAC}+\mathrm{DTAC}$

Where:

$\mathrm{TAC}=$ Total accrual period $\mathrm{t}$

NDTAC $=$ Value of non-discretionary accruals

DTAC $=$ Discretionary accrual

Under the cash flow approach, total accruals are measured as follows:

TACCit=EBXTit

Where:

EBXTit $=$ Earnings before extraordinary items and discontinued operations period $\mathrm{t}$ 
Journal DOI: 10.46654/ij.24889849

Article DOI: 10.46654/ij.24889849.s61221

ANALYSIS AND INTERPRETATION OF RESULT

\section{Test of Hypothesis}

Ho: Operating activities have no significant effect on total accruals earnings of Nigerian Deposit Money Banks.

\section{Table 1: Panel Least Square (PLS) Regression Analysis testing the effect of ENMGT on CFOPA}

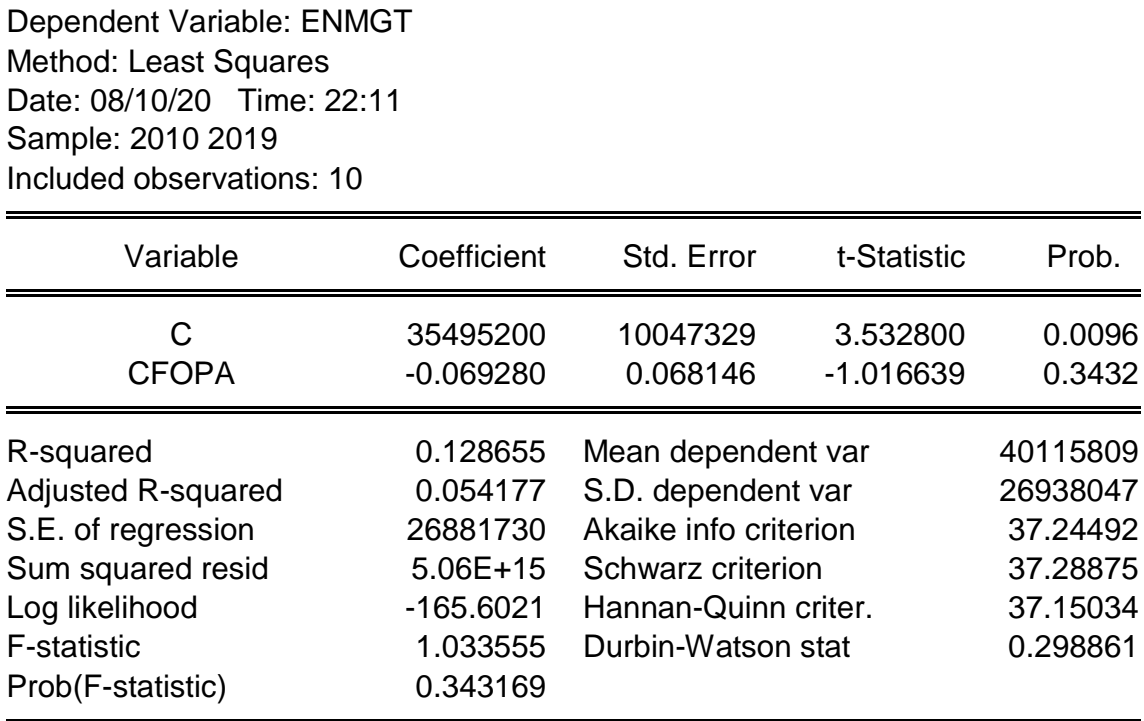

Source: E-Views 9.0 Panel Regression Output, 2020

\section{Interpretation of Regression Result}

Table 1 reveals an adjusted $R^{2}$ value of .054 . The adjusted $R^{2}$, which represents the coefficient of multiple determinations imply that 54\% of the total variation in the dependent variable (ENMGT) of quoted deposit money banks in Nigeria is jointly explained by the explanatory variable (CFOPA). The adjusted $\mathrm{R}^{2}$ of $54 \%$ did not constitute a problem to the study because the F- statistics value of 1.0336 with an associated Prob. $>F=0.343$ indicates that the model is fit to explain the relationship expressed in the study model and further suggests that the explanatory variable is properly selected and used. The value of adjusted $\mathrm{R}^{2}$ of $54 \%$ also shows that $46 \%$ of the variation in the dependent variable is explained by other factors not captured in the study model. This suggests that apart from CFOPA there are other factors that mitigate ENMGT of quoted deposit money banks in Nigeria. The results in table 4.2 illustrated that CFOPA has a negative but significant relationship with ENMGT measured with a beta coefficient $\left(\beta_{1}\right)$ and tvalue of -0.069280 and -1.016639 respectively and $p$ - value of 0.343 which is not statistically significant at 5\%:

$\mathrm{CFOPA}=-0.069280-35495200 \mathrm{ENMGT}+\mu$

This beta coefficient revealed that if ENMGT increases by one unit, then the sampled banks CFOPA would increase by $07 \%$. In addition, Durbin-Watson test is implied to check the auto 
Journal DOI: 10.46654/ij.24889849

correlation among the study variables. The Durbin-Watson value is 0.298861 which is less than 2 provide an evidence of no auto-correlation among the variables.

\section{Decision}

Based on the empirical evidence that suggests that CFOPA has a no significant but negative effect on ENMGT of banks in Nigeria at 5\% level of significance, thus, the null hypothesis of the study is accepted.

Cash flow from Operating Activities (CFOPA): based on finding, cash flow from operating activities has negative effect on our dependent variable, earning management. This effect was not statistically significant. This finding therefore supports our aprori expectation and the findings of Yulius, Arya and Indra (2017) and negates the view of Hossein and Gaskari (2016).

\section{CONCLUSION AND RECOMMENDATION}

This study assessed the effect of operating cash flow on earnings management of Nigerian banks. The study revealed that operating activities are not statistically significant and have a negative effect on the total accruals earnings of Nigerian Banks. These findings illustrate the importance of risk management activities aimed at reducing future cash flow. Furthermore, the results indicate that earnings smoothing accomplished through accrual estimates do not appear to be valued by the market. This is an important distinction from the prior literature and suggests that managers focus their activities on producing smooth cash flows rather than concerning themselves necessarily with reporting smooth earnings via accrual estimates. Moreover, the results also reveal that there is fewer earnings management when operating cash flows are high and that there is more earnings management when political costs, leverage and board size are high.

Therefore, the cash flow volatility has a direct and positive impact on the discretionary accruals, as an indicator of the earnings management. Thus, it can be argued that the fluctuations of the operating cash flow in the Nigerian banks have no significant negative impact on the earnings management.

Based on the findings, the study recommended that Managers should be more likely to opportunistically boost operating cash flows if the firm has a cash flow forecast like engaging in principal financing source for maintaining the operating capability of the entity in terms of repaying loan and making new investment. 


\section{REFERENCES}

Aries, V. (2015).The Influence of Leverage and Its Size on the Earnings Management. Research Journal of Finance and Accounting 6(8). ISSN 2222-1697 (Paper) ISSN 2222-2847 (Online) www.iiste.org

Alves, S. (2012). Ownership Structure and Earnings Management: Evidence from Portugal.,

Bartov, E., Givoly, D. \& Hayn, C. (2002). The rewards to meeting or beating earnings expectations. Journal of Accounting and Economics 33, 173-204.

Bhundia, A. (2012). A comparative study between free cash flows and earnings management. Working paper; Available at http://ssrn.com/abstract

Brown, L. \& Pinello, A. 2011. Firms' propensity to report cash flow and earnings surprises of divergent signs. Working paper.

Chang, R. D., Shen, W. H. A., \& Fang, C. J. (2008). Discretionary loan loss provisions and earnings management for the banking industry. International Business \& Economics Research Journal, 7(3), 9-20.

Call, A. (2009). Analysts' cash flow forecasts and the predictive ability and pricing of operating cash flows. Working Paper.

Cohen, D. A., Dey, A. \& Lys, T. Z. (2008). Real and accrual-based earnings management in the pre- and post-sarbanes Oxley Periods. The Accounting Review 83, 757-788.

Defond, M. \& Hung, M. (2003). An empirical analysis of analysts' cash flow forecasts. Journal of Accounting and Economics 35, 73-100.

Defond, M. \& Hung, M. (2007). Investor protection and analysts' cash flow forecasts around the world. Review of Accounting Studies 12, 377-419.

Dechow, M and Ge, W. 2006. The persistence of earnings and cash flows and the role of special items: Implications for the accrual anomaly, Rev Acc Stud (2006) 11:253-296

Ertimur, Y. \& Stubben, S. (2005). Analysts' incentives to issue revenue and cash flow forecasts. Working paper.

Fatma, B.M. \& Chichti, J. (2011), Interactions between free cash flow, debt policy and structure of

Graham, J. R., Harvey, C. R. \& Rajgopal, S. (2005). The economic implications of corporate financial reporting. Journal of accounting and economics, 40, 3-73.

Gray, R.P., \& Clarke, F.L. (2004). A Methodology for calculating the allowance for loan losses in commercial banks. Abacus, 40 (3), 23-34.

Habib A.. (2004). impact of earnings management on value-relevance of accounting information. Journal of Managerial Finance, 30(11): 1-15.

Hossein, F. \& Reihaneh, G., (2016). Investigation the effect of cash flow volatility and financial leverge on earnings management in the context of listed companies in Tehran Stock Exchange (Iran). International journal of humanities and cultural studies ISSN 23565926 http://www.ijhcs.com/index.php/ijhcs/index Page 2216.

Lanouar, C., Rabeb, R. \& Abdelwahed, O. (2018).The determinant of earnings management in developing countries: A study of the Tunisian Context. https://www.researchgate.net/publication/256056892.

Mohammad, W.M., Wasiuzzaman, S., \& Zaini, R.M. (2011). Panel data analysis of the relationship between earnings management, bank risks, loan loss provision and dividend per share. Journal of Business and Policy Research, 6(1), 46-56. 
Journal DOI: 10.46654/ij.24889849

Musa, A. F. \& Muhammad, A. I. (2018). Earnings Management of Listed Deposit Banks (DMBs) in Nigeria: A Test of Chang, Shen and Fang (2008) Model. International Journal of Finance and Accounting 7(2): 49-55. DOI: 10.5923/j.ijfa.20180702.04

Mcinnis, J. \& Collins, D. W. (2011). The effect of cash flow forecasts on accrual quality and benchmark beating. Journal of Accounting \& Economics, 51, 219-239.

Mehdi, N., Ines, F. B. A., Tawhi, C. \&, Faten, L. (2016). Free cash flow and earnings management: the moderating role of governance and ownership. The Journal of Applied Business ResearchN 32(1).

Nacasius U. U. \&, Jorge B. (2014). Earnings management, financial leverage, and cash flow volatility: an analysis by industry. Journal of Business and Economics, ISSN 2155-7950, USA March 2014, 5(2) pp. 338-348 DOI: 10.15341/jbe(2155-7950)/03.05.2014/005

Nia, D. G., Vaeez, S. A. \& Ahmadi, K. (2013). Investigation the impact of cash flow volatility and financial leverage on earnings management in the context of Listed Companies in Tehran Stock Exchange (Iran). New York Science Journal 6(10).

Norhayati, Z., Rahayu, A. .R. \& Noor S.M. I. (2013). The Impact of Leverage on Real Earnings Management. International Conference on Economics and Business Research 2013 (ICEBR 2013). Procedia Economics and Finance 7 ( 2013 ) 86 - 95

Rahmani, S. \& Akbari, M. A. (2013). Impact of firm size and capital structure on earnings management: evidence from Iran. World of Sciences Journal, 1(17), 59-71.

Roychowdhury, S. (2006). Earnings management through real activities manipulation. Journal of Accounting \& Economics, 42, 335-370.

Slavko, Š. (2015).The impact of fair value accounting on earnings quality in eastern European countries. Emerging Markets Queries in Finance and Business. Procedia Economics and Finance 32; $1769-1786$.

Tarek E. (2017). An empirical investigation of earnings management in the MENA Region A thesis submitted in partial fulfillment of the requirements for the degree of Doctor of Philosophy. University of the West of England.

Yulius, K. S., Arya, P. \& Indra, A. D. (2017). Free cash flow and earnings management: board of commissioner, board independence and audit quality Corporate Ownership \& Control / Volume 14, Issue 4, Summer 2017, Continued - 1-284 